\title{
Changes in Antarctic ice-shelf margins between 1997 and 2019 using Sentinel and RADARSAT data
}

\author{
Esha Shah $^{1, *}$, P. Jayaprasad ${ }^{2}$, M. E. James ${ }^{1}$, Deepak Putrevu ${ }^{2}$ and \\ Arundhati Misra ${ }^{2}$ \\ ${ }^{1}$ Physics Department, Gujarat University, Ahmedabad 380 009, India \\ ${ }^{2}$ Space Applications Centre (ISRO), Ahmedabad 380 015, India
}

\begin{abstract}
We have monitored the changes that have occurred over nine Antarctic ice shelves between 1997 and 2019 using Sentinel-1 and RADARSAT-1 images of Antarctica using change detection technique. The net loss of Antarctic ice shelves during the period was about $14,723 \mathrm{sq} . \mathrm{km}$ in surface area, corresponding to $1.21 \%$ area of ice shelves. The Ross and Filchner-Ronne ice shelves retreated significantly in terms of total area, while shelves in that Antarctic Peninsula, namely Wilkins and Larsen $C$ retreated drastically in terms of percentage change.
\end{abstract}

Keywords: Climate change, change detection, satellite, ice-shelf calving, remote sensing.

ANTARCTIC continent has a long coastline of about $43,449 \mathrm{~km}$, of which about $75 \%$ is covered by ice shelves $^{1}$ which represents about $11 \%$ of its area ${ }^{2}$. The position of ice-shelf front advances when more ice flows from land or due to accumulation of snowfall, and it retreats when the iceberg calves off its edges. Driving forces responsible for advance and retreat of ice fronts vary depending on the region and interval of observation. Baumhoer et $a l^{3}$ reviewed major studies related to changes in the Antarctic coastline and gave an insight into the various processes influencing the frontal position of ice shelves.

Iceberg calving rates vary considerably in both time and space, depending on complex interactions involving outlet glacier velocity, bedrock topography, degree of crevassing, temperature of atmosphere and ocean, sea-ice conditions and extent, tidal forcing, and ocean waves. Several researchers consider the retreat of ice sheets as a strong indication of global climate change ${ }^{4-6}$. Since ice shelves are exposed to both warming air above and warming ocean below, they respond more quickly to rising temperatures than ice sheets. Sea ice, especially fast ice surrounding the Antarctic continent generally provides a layer of protection between the ice shelf and the

*For correspondence. (e-mail: eshu7456@gmail.com) surrounding ocean. However, as the temperature increases the extent of sea ice decreases, which reduces the stability of ice shelves. Owing to global warming, frequent ice-shelf disintegration and rapid acceleration of inland ice flow have been observed, affecting the Antarctic mass balance and global sea level ${ }^{7}$. It was reported that some of the ice shelves had disintegrated abruptly following abnormal warm summers ${ }^{5,6,8,9}$. Larger iceshelves such as Ross and Filchner-Ronne which are located in colder climates, exhibit calving in the time span of decades or even centuries between major events. Major calving events over the Antarctic ice shelves occur sporadically with long recurrence intervals ${ }^{10,11}$. Paolo et al. ${ }^{12}$ reported that the losses in West Antarctica have increased by $70 \%$ in the last decade and the earlier volume gain by East Antarctic ice shelves has ceased. Under the present scenario of climate change, monitoring the stability of these ice shelves and recent changes in the ice-shelf margins is crucial.

Remote sensing is an important tool for monitoring coastal margins of Antarctica for analysing and predicting changes in the area of ice shelves. Baumhoer et al. $^{3}$ summarized the advantages and disadvantages of different techniques for mapping the Antarctic coastline. Change detection is one of the techniques used to identify differences in the surface features by analysing a pair of images acquired in the same geographical area at different times. Using medium-resolution MODIS data, Patel et $a l{ }^{13}$ developed a mosaic of Antarctic coastline of 2016 and performed the change detection analysis with reference to RADARSAT mosaic image (1997). They found that over East Antarctica, total areas of advancement and retreat are nearly the same, but over West Antarctica, the area of retreat is significantly higher compared to the area of advancement.

A preliminary analysis revealed that nine ice shelves around Antarctica have shown significant changes in their margins. In the present study, effort was made to obtain better estimates of recent changes that occurred over these nine Antarctic ice shelves, using high-resolution Synthetic Aperture Radar (SAR) data. 


\section{Study area and data used}

The study area covers nine major Antarctic ice shelves, namely Filchner-Ronne, Ross, Riiser-Larsen, Wilkins, Larsen C, Fimbul, Amery Shackleton and West. Figure 1 shows these selected ice-shelves in the RADARSAT mosaic image of Antarctica ${ }^{4}$.

For change detection analysis, the RADARSAT-1 mosaic of Antarctica (1997) was used as the base image $^{14}$. RADARSAT-1 carried on-board an advanced SAR with $125 \mathrm{~m}$ resolution. The RADARSAT mosaic of Antarctica has been downloaded from the National Snow and Ice Data Center website (https://nsidc.org/data/ RADARSAT/data_summaries.html). The RAMP Antarctic Mapping Mission (AMM-1) product coastline shapefiles of 1997 were downloaded from the Alaska Satellite Facility website (https://www.asf.alaska.edu/other-data/ ramp/amm1/ramp-data/). The Sentinel-1 satellite operating in the $\mathrm{C}$-band provides images with 12 days of repeat cycle $^{15}$. Sentinel-1 level-1 ground range detected (GRD) product in medium resolution $(40 \mathrm{~m})$ with $\mathrm{HH}$ polarization, covering the coastal margins of major ice shelves were acquired from Copernicus Open Access Hub (https://scihub.copernicus.eu/dhus/\#/home) for the period January to April 2019. These have been used as the second image for change detection analysis. The

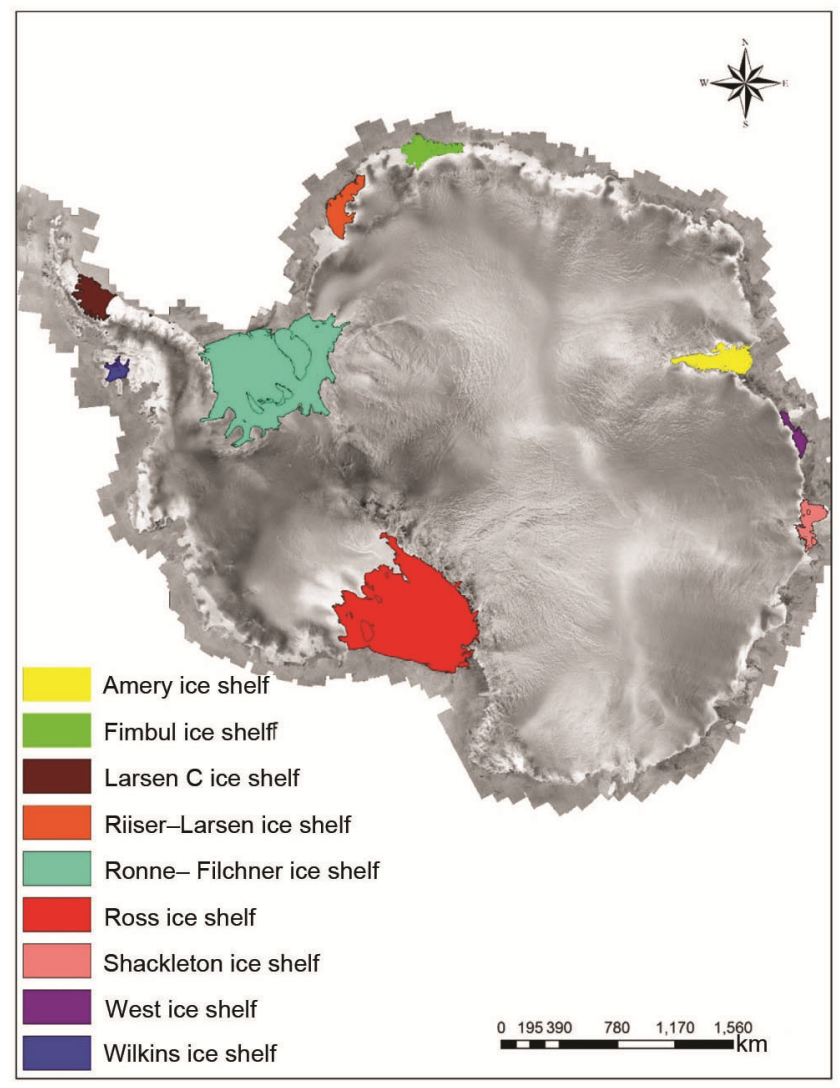

Figure 1. Major ice shelves of Antarctica shown on the RADARSAT mosaic image of 1997. shapefiles of the coastline covering ice shelves in 2019 were downloaded from the Antarctic Digital Database Map Viewer (https://www.add.scar.org/). For comparison, mosaic of Antarctica (MOA-2003; downloaded from https://www.nsidc.org) generated using MODIS measurements made during November/December 2003 with spatial resolution of $250 \mathrm{~m}$ was used.

\section{Methodology}

Figure 2 shows a flow chart depicting the methodology for performing change detection analysis and estimating the changes in surface area over the ice shelves. The Sentinel GRD product consists of SAR data that have been detected, multi-looked and projected to ground range using an earth ellipsoid model ${ }^{16}$. Sentinel-1 data acquired were pre-processed using the Sentinel Application Platform (SNAP 6.0) software. The data were subjected to speckle removal using refined Lee filter ${ }^{17}$. Geometric correction of the image was done using ellipsoid correction, which determines the latitude, longitude and slant range time of the source image from localization geolocation grid annotation dataset (LADS).

The subsets of each ice shelve were created from the RADARSAT product and used as the first image for change detection analysis. To maintain the same spatial resolution for both RASARSAT-1 and Sentinel-1 images,

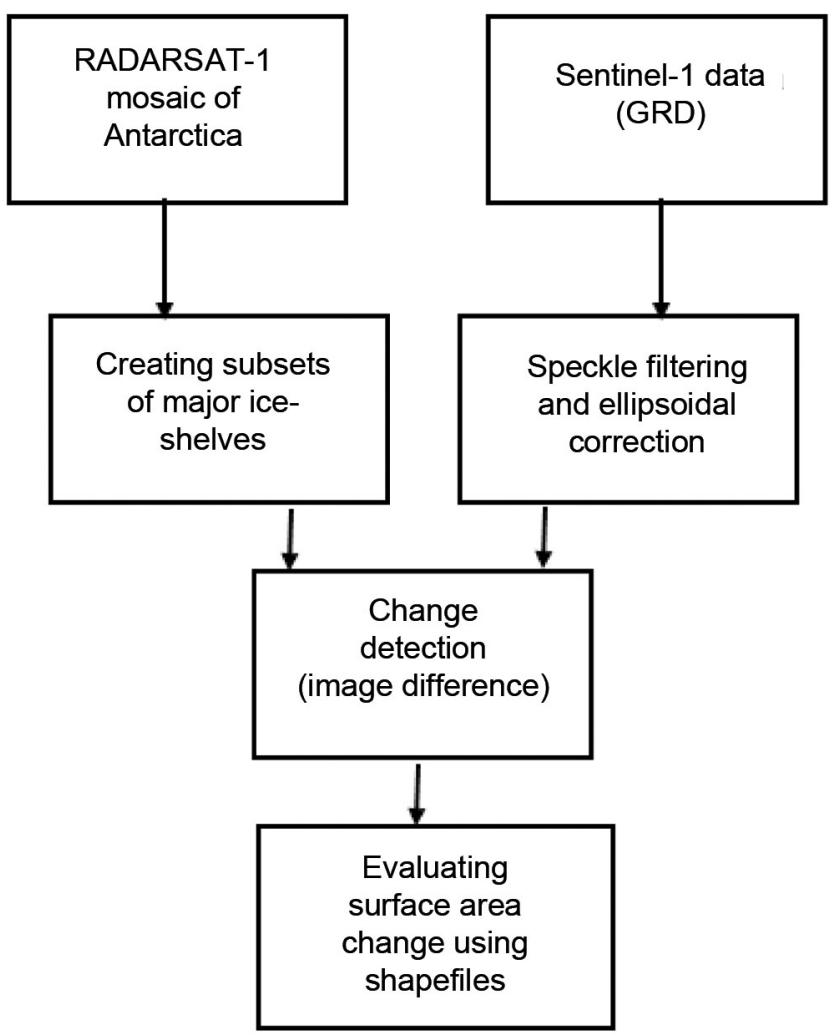

Figure 2. Methodology.

CURRENT SCIENCE, VOL. 119, NO. 10, 25 NOVEMBER 2020 
the latter images were resampled to the RADARSAT-1 image resolution of $125 \mathrm{~m}$ using the nearest neighbour method and then re-projected to polar stereographic south projection.

For change detection analysis, the image difference technique available in ERDAS IMAGINE 2015 software was utilized. In this method, the registered images acquired at different times are subtracted at the pixel level to produce a difference image which represents the changes between the two dates. This difference image is a grey-scale image composed of single-band data. For a better interpretation of the changes that have occurred in the ice margins, the RADARSAT-1 subset image, Sentinel-1 image and difference image were layer-stacked and an RGB false colour composite (FCC) was generated. From the layer-stacked images, changes in the area of the ice margins between 1997 and 2019 were estimated.

Area of each ice shelf during 1997 and 2019 was estimated using RADARSAT (1997) and Sentinel (2019) shapefiles. The RADARSAT-1 shapefiles (1997) contain only the coastline of Antarctica, while shape files derived from Sentinel-1 contain the entire ice-shelf boundaries of 2019. Since the inner boundaries of ice shelves are not expected to change, the ice-shelf margin shapefiles of RADARSAT- 1 were extrapolated with the inner boundaries of the ice shelf from Sentinel-1 shapefiles to get the area of ice shelves in 1997. The area of each ice shelf was also estimated using MODIS image mosaic MOA-2003 (ref. 18). Using these three datasets, a comparison of changes in area between 1997-2003 and 2003-2019 was made for each iceshelf.

\section{Results and discussion}

In the layer-stacked change detection FCC image, red colour represents the retreat (calving), indicating a decrease in the area from 1997 to 2019 and greyish-blue colour represents advancement in the ice margins in 2019 compared to 1997. For easy discrimination of changes in the ice shelf, the advanced/retreated margins of 2019 in change detection FCC images have been highlighted with yellow/green colour respectively. Detailed analysis of changes in the area of all ice shelves individually is described in the following sections.

\section{Amery ice shelf}

Figure $3 a$ and $b$ show the ice margin image of the Amery ice shelf in 1997 obtained as the subset of the RADARSAT mosaic image and ice-margin image of 2019 obtained from Sentinel data respectively. Figure $3 c$ shows the difference image generated using ERDAS software. Figure $3 d$ presents the change detection FCC image with RGB combination of the above three images. The greyish-blue region with yellow border over the ice margin of the Amery ice shelf (Figure $3 d$ ) manifests an advancement of ice margin to the sea from 1997 to 2019, which is about $4285 \mathrm{sq} . \mathrm{km}$ in area. Fricker et al. ${ }^{10} \mathrm{stu}-$ died changes in ice margins of Amery ice shelf based on different datasets and reported the occurrence of a major calving event between 1963 and 1965. They mentioned that the Amery ice-shelf calving cycle has a period of about 60-70 years and the Amery ice-shelf front will not experience any major calving events until the mid-2020s. They also observed two longitudinal rifts at the Amery ice-shelf front in 2000 of length 15 and $26 \mathrm{~km}$, separated by about $25 \mathrm{~km}$. They indicated the presence of a transverse fracture of about $6 \mathrm{~km}$ between these longitudinal rifts, and forecasted a major ice-shelf calving when this transverse rift meets the longitudinal rifts. Recently, Darji et $a l .{ }^{19}$ studied the propagation of five active rifts in the Amery ice shelf during the period 2000-17 and predicted two major potential calving zones over it, the 'loose tooth' with an area of about $842 \mathrm{sq} . \mathrm{km}$ and another with an area of about 1518 or 1797 sq. km. The Sentinel image of 2019 (Figure $3 b$ ) clearly shows that the rifts have already propagated a long way. On 26 September 2019, a large tabular iceberg named D-28 with an area of $1636 \mathrm{sq} . \mathrm{km}$ calved from the Amery ice shelf $\mathrm{f}^{20}$. This is the first major calving event on the Amery ice shelf since 1963/64 (ref. 21).

\section{Ross ice shelf}

The change detection image of the Ross ice shelf presented in Figure 4 clearly indicates a significant reduction in area from 1997 to 2019 (9469 sq. km). Patel et $a l .{ }^{13}$ reported that both sides of the Ross ice shelf had retreated during the period 1997-2016, but the middle

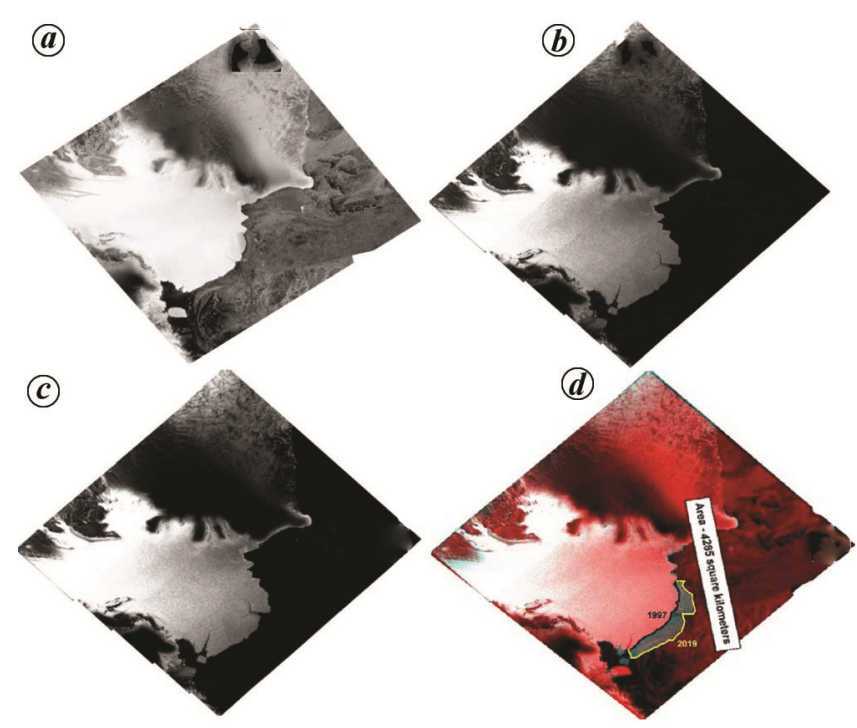

Figure 3. Amery ice-shelf margin. $\boldsymbol{a}$, Subset of RADARSAT mosaic image of 1997. $\boldsymbol{b}$, Sentinel image of 2019. $\boldsymbol{c}$, Difference image between 1997 and 2019. $\boldsymbol{d}$, Change detection FCC image. 


\section{RESEARCH ARTICLES}

portion had advanced by 1758 sq. km during the same period. Major disintegration of the Ross ice shelf took place in March 2000, when the world's largest iceberg, as of now, named B-15 with an area of 10,915 sq. km calved off from the East Ross ice shelf ${ }^{11}$. Similarly, another major calving of the Ross ice shelf occurred on May 2002, when the iceberg C-19 with an area of about 5500 sq. km separated from the western face of the ice shelf. The Ross ice shelf has remained almost stable after these massive losses.

\section{Filchner-Ronne ice shelf}

The change detection FCC image of the Filchner-Ronne ice shelf between 1997 and 2019, shown in Figure 5 reveals a net retreat of $4168 \mathrm{sq}$. $\mathrm{km}$ in area. It is interesting to note that the Ronne ice shelf has shown retreat, whereas the Filchner ice shelf has shown advancement during this period. A major calving event over the Filchner ice shelf occurred in April 1986 which resulted in an area loss of about $11,500 \mathrm{sq} . \mathrm{km}$, after which it

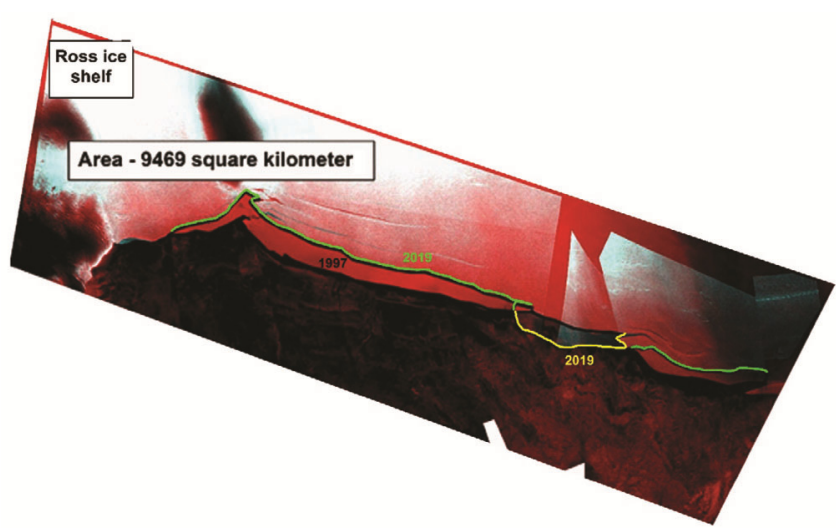

Figure 4. Change detection image of Ross ice shelf.

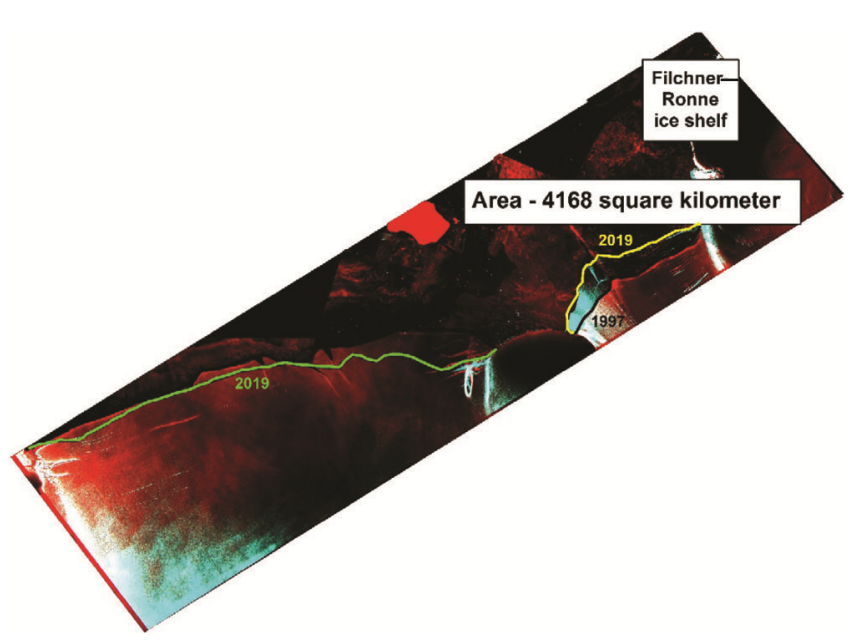

Figure 5. Change detection image of Filchner-Ronne ice shelf. Mark 1997 boundary with black line. continued to advance ${ }^{22}$. Li et al. ${ }^{23}$ reported that the Filchner ice shelf front is an active fracturing region with two major transverse rifts close to the front measuring about $50 \mathrm{~km}$, and that these rifts may potentially lead to major calving events around 2051. The most notable disintegrations over the Ronne ice shelf occurred in 1998 and 2000, with a total loss in area of $16,300 \mathrm{sq} . \mathrm{km}$, which removed the ice front accumulated since the late 1940s and early 1950s (refs 23, 24). After these calving events, the Ronne ice shelf has exhibited advancement trend. Hulbe et al. ${ }^{25}$ reported that the long rifts observed near the front of the ice shelf are propagating along the lateral boundaries of outlet streams feeding the shelf and may result in huge calving in the future.

\section{Larsen C ice shelf}

The change detection FCC image of the Larsen $\mathrm{C}$ iceshelf shown in Figure 6 indicates a large retreat of ice margin during the period 1997-2019. Estimation shows that the retreated area is $5482 \mathrm{sq} . \mathrm{km}$. This is due to the major calving event that occurred on 12 July 2017 (ref. 26). A large portion, about 5800 sq. $\mathrm{km}$, of the ice shelf had broken off from the main ice shelf and formed an iceberg, designated A-68, reduced the size of the Larsen $\mathrm{C}$ ice shelf by around $12 \%$. This is recorded as the largest calving event in the Antarctic Peninsula and that too within three years of the formation of rift.

\section{Riiser-Larsen ice shelf}

Figure 7 represents the change detection FCC image of the Riiser-Larsen ice-shelf, which reveals a marginal advance of ice margin (129 sq. $\mathrm{km}$ ) to the sea between

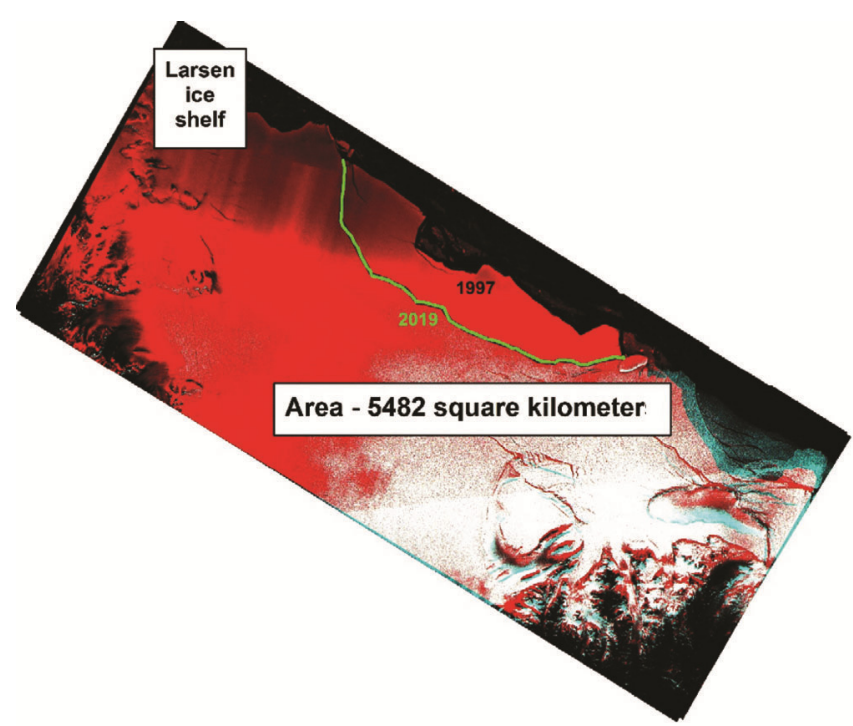

Figure 6. Change detection image of Larsen $\mathrm{C}$ ice shelf.

CURRENT SCIENCE, VOL. 119, NO. 10, 25 NOVEMBER 2020 
1997 and 2019, suggesting an almost stable state of the ice shelf during that period.

\section{Fimbul ice shelf}

The change detection image of the Fimbul ice shelf presented in Figure 8 shows its advancement to the sea during 1997-2019. Estimation shows the advancement to be about 709 sq. km. The Fimbul ice shelf gains its mass from the Jutulstraumen Glacier. Humbert and Steinhage ${ }^{27}$ observed several crevasses and rifts under the Fimbul ice shelf, which are under propagation. The western rift area of the Fimbul ice shelf covering $30 \mathrm{~km}$ in width and $100 \mathrm{~km}$ in length may lead to large calving in the future, similar to the one witnessed during 1967.

\section{Shackleton ice shelf}

The change detection image of the Shackleton ice shelf presented in Figure 9 shows an advance on the eastern

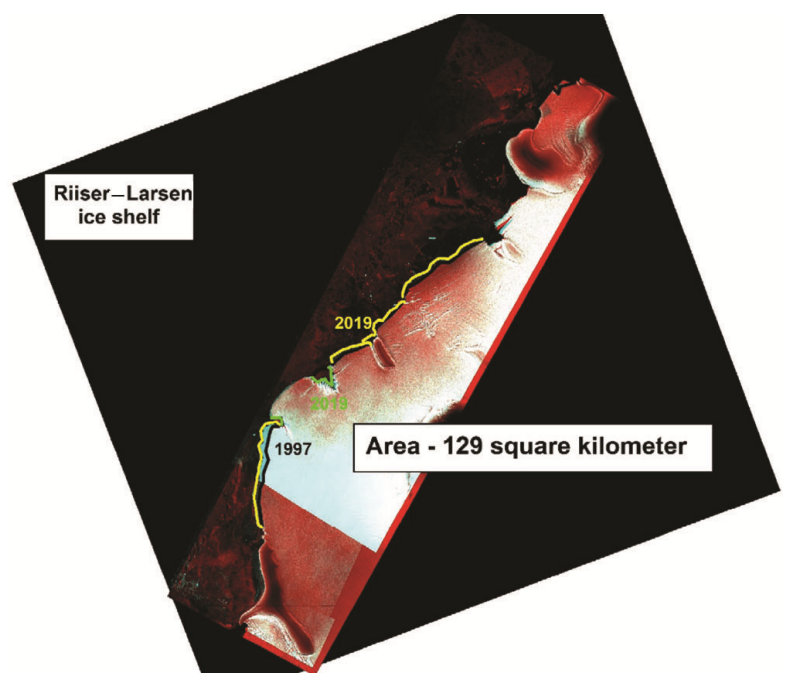

Figure 7. Change detection image of Riiser-Larsen ice shelf.

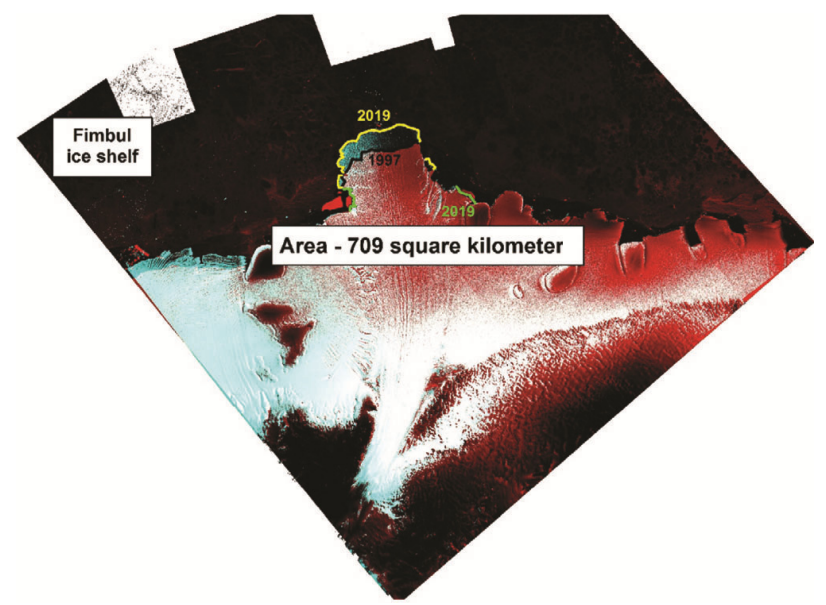

Figure 8. Change detection image of Fimbul ice shelf. side. It gained a surface area of 874 sq. km between 1997 and 2019. It is clear from the figure that the Denman Glacier tongue advanced from 1997 to 2019, whereas the Scott Glacier tongue had retreated during the same period.

\section{West ice shelf}

The change detection image presented in Figure 10 shows that the area of the West ice shelf has increased by

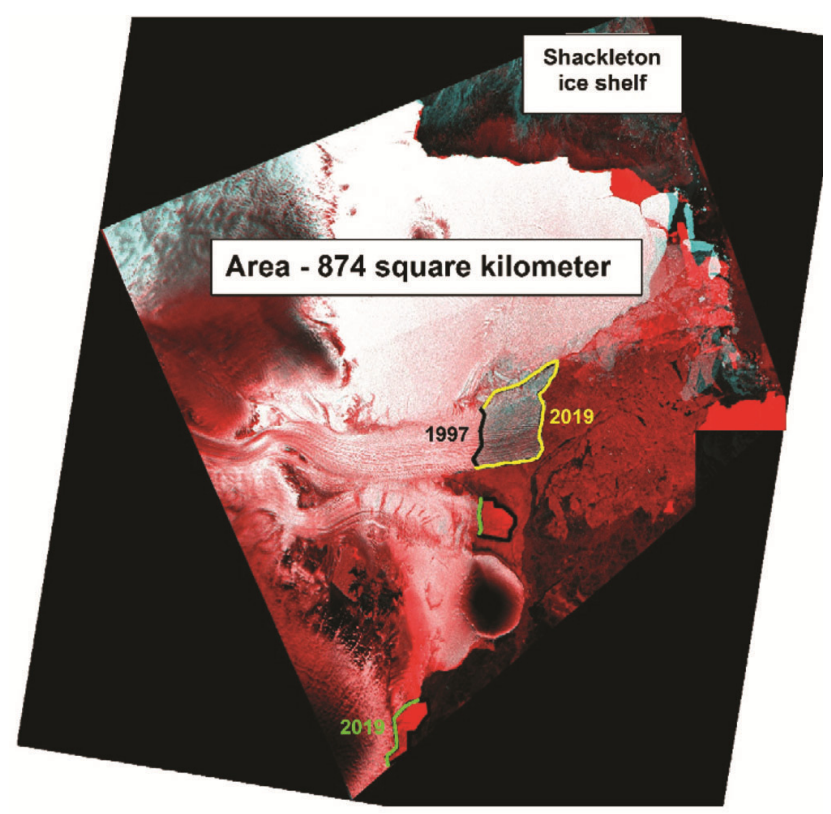

Figure 9. Change detection image of Shackleton ice shelf.

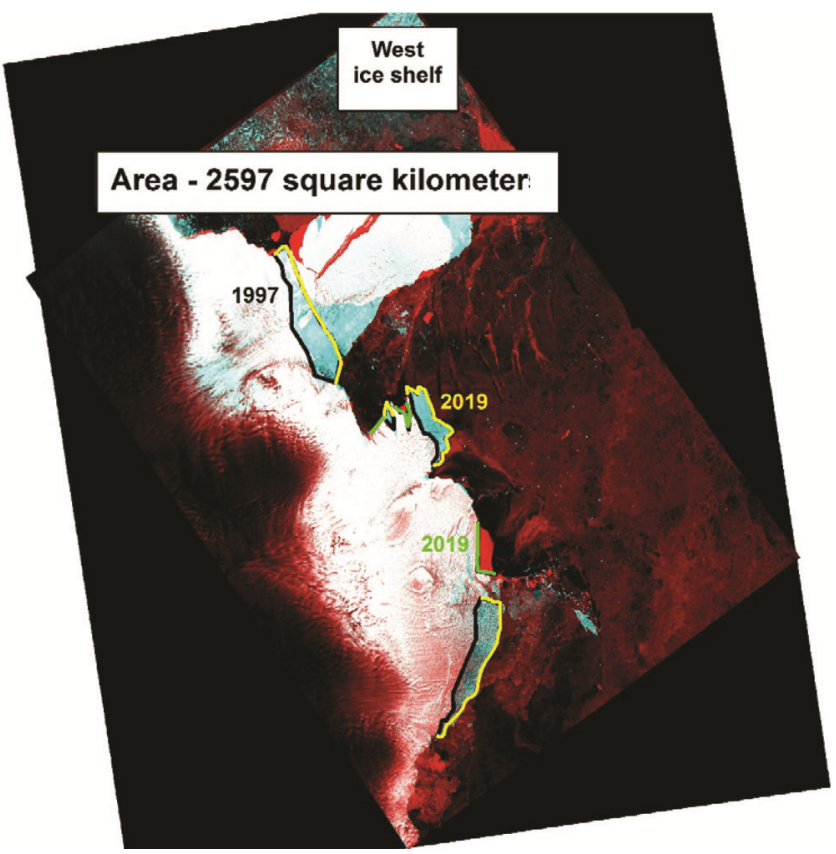

Figure 10. Change detection image of west ice shelf. 


\section{RESEARCH ARTICLES}

2597 sq. km between 1997 and 2019. During this period, there were no calving events reported over the ice shelf.

\section{Wilkins ice shelf}

The change detection image of the Wilkins ice shelf presented in Figure 11 clearly shows a retreat of ice margin during 1997-2019. Estimates from the figure show a partial disintegration of 4198 sq. $\mathrm{km}$ in area during the period. Significant break-ups of the ice-shelf occurred in March 1998, March/July 2008 and April 2009, resulting in a total reduction of $5434 \mathrm{sq} . \mathrm{km}$ area ${ }^{28}$.

\section{Relative changes in the area of Antarctic ice shelves}

Figure 12 shows percentage changes in the area of ice shelves from 1997 to 2019 with respect to those in 1997 on the map of Antarctica. Table 1 summarizes the changes in the area of ice shelves based on change detection analysis and percentage difference in area with reference to 1997 condition. During the period 1997-2019, different ice-shelf margins of Antarctica together retreated by 23,317 sq. $\mathrm{km}$ and advanced by $8594 \mathrm{sq} . \mathrm{km}$ resulting in a net loss of about 14,723 sq. $\mathrm{km}$ of surface area, which corresponds to a net loss of $1.19 \%$ area of the ice shelves studied. During the same period, retreat of ice margins was observed over Ross (-9469 sq. km), Larsen C (-5482 sq. km), Filchner-Ronne (-4168 sq. km) and Wilkins ( -4198 sq. km) ice shelves. Similarly, whereas advancement was observed over Amery (4285 sq. km), west (2597 sq. km), Shackelton (874 sq. km) and Fimbul (709 sq. km) ice shelves during the same period. The

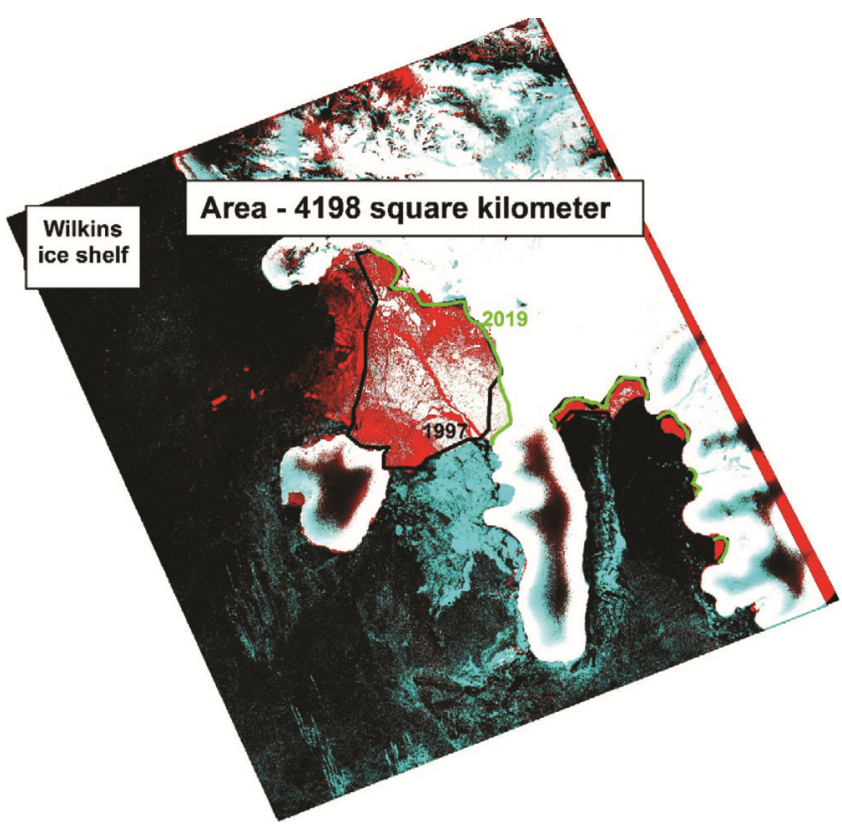

Figure 11. Change detection image of Wilkins ice shelf.
Riiser-Larsen ice shelf was found to be the most stable during the period of study. In terms of percentage change, the maximum loss of 29.24 occurred over the Wilkins ice shelf followed by the Larsen C ice shelf (10.76); both occurred over the Antarctic Peninsula. Similarly, maximum gain in terms of percentage change occurred over the west ice shelf (16.38) followed by the Amery ice-shelf (6.94). It is important to note that, in general, advancements had taken place over the eastern part of Antarctica while retreats were observed over the western part, especially over the Antarctic Peninsula.

\section{Comparison of changes in the area of Antarctic ice shelves between 1997-2003 and 2003-2019}

Table 2 shows a comparison of areas of ice shelves estimated based on RADARSAT measurements with $125 \mathrm{~m}$ resolution carried out during September/October 1997, MODIS measurements made in November/December

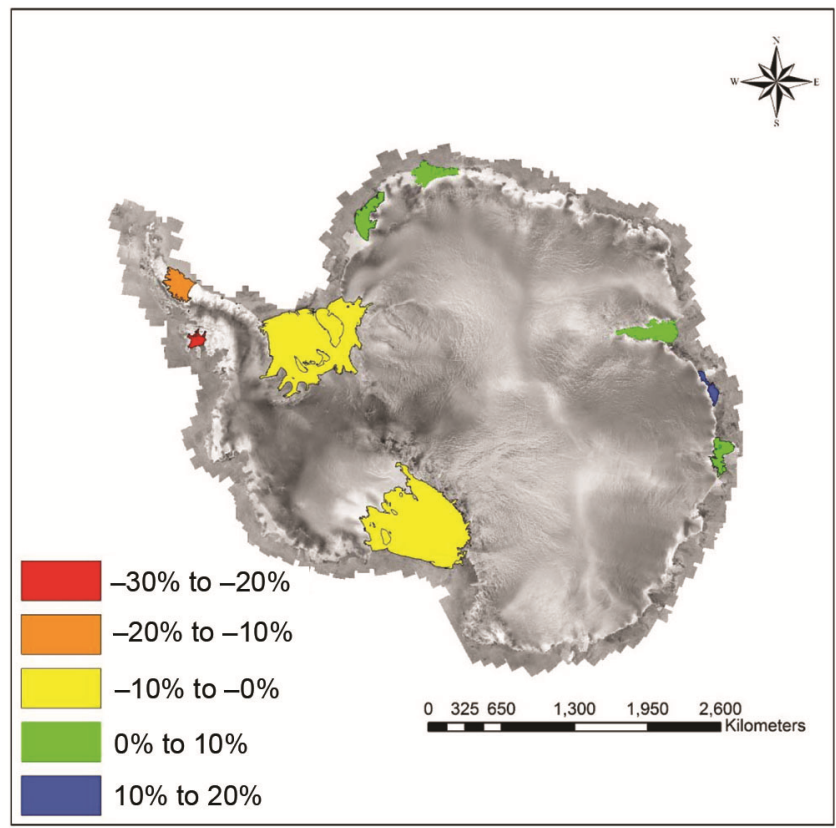

Figure 12. Percentage changes in the area of ice shelves between 1997 and 2019 on the map of Antarctica.

Table 1. Change in the area of Antarctic ice-shelves between 1997 and 2019 based change detection technique

\begin{tabular}{lc}
\hline Ice shelf & Change in area (sq. km) and \% change \\
\hline Ross & $-9469(-1.86)$ \\
Filchner-Ronne & $-4168(-0.91)$ \\
Amery & $+4285(+6.94)$ \\
Larsen C & $-5482(-10.76)$ \\
Riiser-Larsen & $+129(+0.27)$ \\
Fimbul & $+709(+1.76)$ \\
Shackleton & $+874(+2.58)$ \\
West & $+2597(+16.38)$ \\
Wilkins & $-4198(-29.24)$ \\
\hline
\end{tabular}


RESEARCH ARTICLES

Table 2. Change in area of Antarctic ice shelves between 1997-2003 and 2003-2019 using shapefiles

\begin{tabular}{|c|c|c|c|c|c|}
\hline \multirow[b]{2}{*}{ Ice-shelf } & \multicolumn{3}{|c|}{ Area of ice-shelf in } & \multirow{2}{*}{$\begin{array}{c}\text { Change in area } \\
\text { (sq. km) and \% } \\
\text { change 1997-2003 }\end{array}$} & \multirow{2}{*}{$\begin{array}{c}\text { Change in area } \\
\text { (sq. km) and \% } \\
\text { change 2003-2019 }\end{array}$} \\
\hline & $\begin{array}{l}1997 \text { (sq. km) } \\
\text { RADARSAT }\end{array}$ & $\begin{array}{c}2003 \text { (sq. km) } \\
\text { MODIS }\end{array}$ & $\begin{array}{c}2019 \text { (sq. km) } \\
\text { Sentinel }\end{array}$ & & \\
\hline Ross & 508,276 & 472,960 & 498,301 & $-35,316(-6.95)$ & $+25,341(+5.36)$ \\
\hline Filchner-Ronne & 459,862 & 422,420 & 455,577 & $-37,442(-8.14)$ & $+33,157(+7.85)$ \\
\hline Amery & 61,742 & 62,620 & 66,039 & $+878(+1.42)$ & $+3419(+5.46)$ \\
\hline Larsen C & 50,969 & 48,600 & 45,702 & $-2369(-4.65)$ & $-2898(-5.96)$ \\
\hline Riiser-Larsen & 47,381 & 48,180 & 47,509 & $+799(+1.68)$ & $-671(-1.39)$ \\
\hline Fimbul & 40,394 & 41,060 & 41,100 & $+666(+1.65)$ & $+40(+0.10)$ \\
\hline Shackleton & 33,922 & 33,820 & 34,817 & $-102(-0.30)$ & $+997(+2.95)$ \\
\hline West & 15,856 & 16,370 & 18,438 & $+519(+3.27)$ & $+2068(+12.63)$ \\
\hline Wilkins & 14,355 & 13,680 & 10,204 & $-675(-4.70)$ & $-3476(-24.2)$ \\
\hline
\end{tabular}

2003 with spatial resolution of $250 \mathrm{~m}$ and Sentinel data with $40 \mathrm{~m}$ resolution obtained for the period January to April 2019. The percentage changes for all three cases have been calculated based on the area of the ice shelves in 1997. There are marginal differences in change in area between 1997 and 2019 obtained from change detection analysis and change in area estimated from shapefiles, mainly due to difference in the resolution of images and partly due to errors in drawing the boundaries.

MODIS data of 2003 show significant decrease in the area of Ross ice shelf compared to that in 1997 (-6.95\%). This is mainly due to the two major iceberg calving events that occurred in 2000 and 2002. After 2003, the area of the Ross ice shelf increased by about $5 \%$ with an average of 1689 sq. $\mathrm{km}$ year $^{-1}$. Similarly, the area of the Filchner-Ronne ice shelf reduced significantly by $8.14 \%$ in 2003 compared to that in 1997, mainly due to the two major iceberg calvings, viz. A-38 in 1998 and A-43 in 2000. During the period 2003-2019, the area of the Filchner-Ronne ice shelf increased at an average rate of 2210 sq. $\mathrm{km} \mathrm{year}^{-1}$. It was found that the reduction in area of both Ross and Filchner-Ronne ice shelves in 2003 was much more compared to the size of the calved icebergs, suggesting that several smaller-sized ice-calving events might have occurred in the region during this period. The Larsen $\mathrm{C}$ ice-shelf area decreased during both periods; reduction during 2003-2019 was mainly due to the calving in 2017. The area of the Wilkins ice shelf reduced significantly (24.2\%) during 2003-2019 because several calving events occurred in 1998, 2008 and 2009. Area of the Amery ice shelf increased during both periods, but the rate of increase during the period 2003$2019\left(228 \mathrm{~km} \mathrm{year}^{-1}\right)$ was much more than that period 1997-2003 (146 km year $\left.{ }^{-1}\right)$. The area of the West ice shelf increased at a rate of $86 \mathrm{sq} . \mathrm{km}$ year $^{-1}$ during $1997-$ 2003 , but it increased to 138 sq. $\mathrm{km}$ year $^{-1}$ during the latter period. During the period 1997-2003, the Fimbul ice shelf expanded in area at an average rate of 111 sq. km year ${ }^{-1}$, but during the period 2003-2019, the ice shelf was nearly stable. The area of Riiser-Larsen ice shelf slightly increased during 1997-2003 and nearly equal during 2003-2019. The area of the Shackleton iceshelf reduced slightly during the period 1997-2003, but during the period 2003-2019, the area increased at a rate of $66 \mathrm{sq} . \mathrm{km}$ year $^{-1}$. It is interesting to note that during 1997-2003, major ice shelves over Antarctica retreated significantly with a net reduction of about $5.92 \%$ in area. On the other hand, during 2003-2019, significant advancements have been observed over a number of ice shelves, with a net increase of $4.7 \%$ in area.

\section{Conclusion}

During the period 1997-2019, different ice shelves of Antarctica retreated by 23,317 sq. $\mathrm{km}$ and advanced by 8549 sq. $\mathrm{km}$, resulting in a net loss in surface area of about $14,723 \mathrm{sq} . \mathrm{km}$, which corresponds to a loss of $1.21 \%$ area of ice shelves. Significant retreats in terms of actual area were observed at the Ross, Larsen C, Filchner-Ronne and Wilkins ice shelves. In terms of percentage, maximum disintegration occurred over the Wilkins ice shelf (29.24). Over the Ross and Filchner-Ronne ice shelves, the net change between 1997 and 2019 showed retreats, but 2003 onwards the ice shelves have been advancing at rates of the order of 1689 and 2210 sq. km year ${ }^{-1}$ respectively. The Amery and West ice shelves, both on the eastern coast of Antarctica are continuously advancing with an increased rate during 20032019 compared to that in 1997-2003. Since the changes in ice margins are found to depend on the period as well as location, the study may be extended to temporal analysis of changes in ice margins at all ice shelves, which will help in a better understanding of the calving cycle and future predictions.

1. Liu, H. and Jezek, K. C., A complete high-resolution coastline of Antarctica extracted from orthorectified Radarsat SAR imagery. Photogramm. Eng. Remote Sensing, 2004, 70, 605-616.

2. Drewry, D. J. (ed.), Antarctic Ice Sheet Thickness and Volume, Glaciological and Geophysical Folio, Scott Polar Research Institute, University of Cambridge, UK, 1983. 
3. Baumhoer, C. A. et al., Remote sensing of Antarctic glacier and ice shelf front dynamics - a review. Remote Sensing, 2018, 10, 1445 .

4. Williams Jr, R. S. and Hall, D. K., Glaciers, Atlas of Satellite Observations Related to Global Change, Cambridge University Press, Cambridge, UK, 1993, pp. 401-422.

5. Vaughan, D. G. and Doake, C. S. M., Recent atmospheric warming and retreat of ice-shelves on the Antarctic Peninsula. Nature, 1996, 379, 328-331.

6. Scambos, T. A. et al., The link between climate warming and break-up of ice-shelves in the Antarctic Peninsula. J. Glaciol., 2000, 46, 516-530.

7. De Angelis, H. and Skvarca, P., Glacier surge after ice-shelf collapse. Science, 2003, 299, 1560-1562.

8. Rott, H. et al., Climatically induced retreat and collapse of northern Larsen Ice-shelf, Antarctic Peninsula. Ann. Glaciol., 1998, 27, 86-92.

9. Scambos, T. et al., Climate-induced ice-shelf disintegration in the Antarctic Peninsula. Antarctic Peninsula Climate Variability: Historical and Palaeoenvironmental Perspectives. Antarct. Res. Ser., 2003, 76, 335-347.

10. Fricker, H. A. et al., Iceberg calving from the Amery ice-shelf, East Antarctica. Ann. Glaciol., 2002, 34, 241-246.

11. Lazzara, M. A. et al., On the recent calving of icebergs from the Ross ice-shelf. Polar Geogr., 2008, 31, 15-26.

12. Paolo, F. S. et al., Volume loss from Antarctic ice-shelves is accelerating. Science, 2015, 348, 327-331.

13. Patel, S. et al., Changes in Antarctic coastline between 1997 and 2016 using RADARSAT and MODIS data. Int. J. Remote. Sensing, 2019, 41, 1-26.

14. Jezek, K. C., Glaciological properties of the Antarctic ice sheet from RADARSAT-1 synthetic aperture radar imagery. Ann. Glaciol., 1999, 29, 286-290.

15. Abdikan, S. et al., Land cover mapping using Sentinel-1 SAR data. Int. Arch. Photogramm, Remote Sensing Spat. Inf. Sci., 2016, 41, 757-761.

16. Nagler, T. et al., Advancements for snowmelt monitoring by means of Sentinel-1 SAR. Remote Sensing, 2016, 8, 348.

17. Lee, J.-S., Speckle suppression and analysis for synthetic aperture radar images. Opt. Eng., 1986, 25, 255636; doi:org/10.1117/ 12.7973877

18. Scambos, T. A. et al., MODIS-based mosaic of Antarctica (MOA) data sets: continent-wide surface morphology and snow grain size. Remote Sensing Environ., 2007, 111, 242-257.
19. Darji, S. et al., Rift assessment and potential calving zone of Amery Ice-shelf, East Antarctica. Curr. Sci., 2018, 115, 1799.

20. Australian Antarctic Division, Gigantic iceberg breaks off East Antarctica, 1 October 2019; https://www.antarctica.gov.au/ news/2019/gigantic-iceberg-breaks-off-east-antarctica/.

21. Budd, W., The dynamics of the Amery ice-shelf. J. Glaciol., 1966, 6, 335-358.

22. Ferrigno, J. G. and Gould, W. G., Substantial changes in the coastline of Antarctica revealed by satellite imagery. Polar Rec., 1987, 23, 577-583.

23. Li, R. et al., A systematic study of the fracturing of RonneFilchner ice-shelf, Antarctica, using multisource satellite data from 2001 to 2016. Cryosphere Discuss., 2017, 1-38; https://doi. org/10.5194/tc-2017-178

24. Ferrigno, J. G. et al., Coastal-change and glaciological map of the Ronne ice-shelf area, Antarctica, 1974-2002. In Geologic Investigations Series Map (No. 2600-D), US Geological Survey, 2005.

25. Hulbe, C. L. et al., Propagation of long fractures in the Ronne iceshelf, Antarctica, investigated using a numerical model of fracture propagation. J. Glaciol., 2010, 56, 459-472.

26. Yeager, A., Delaware-sized iceberg breaks off Antarctic ice shelf. Science News, 12 July 2017; https://www.sciencenews.org/article/ delaware-sized-iceberg-breaks-antarctic-ice-shelf

27. Humbert, A. and Steinhage, D., The evolution of the western rift area of the Fimbul Ice-shelf, Antarctica. Cryosphere, 2011, 5, 931-944.

28. Davies, B., Antarctic peninsula ice shelves, Antarctic glaciers. 19 June 2017; http://www.antarcticglaciers.org/glaciers-and-climate/ shrinking-ice-shelves/antarctic-peninsula-ice-shelves/.

ACKNOWLEDGEMENTS. We thank the Space Applications Centre (SAC; ISRO), Ahmedabad for providing a research grant under the MOP-III programme and DST and UGC for financial assistance to the Physics Department, Gujarat University, Ahmedabad under FIST and SAP programmes respectively. We also thank Director (SAC) and Dr Raj Kumar (SAC) for their keen interest in this study, and the anonymous reviewer for useful suggestions.

Received 5 April 2020; revised accepted 27 August 2020

doi: $10.18520 / \mathrm{cs} / \mathrm{v} 119 / \mathrm{i} 10 / 1633-1640$ 